einstein

Official Publication of the Instituto Israelita

de Ensino e Pesquisa Albert Einstein

ISSN: 1679-4508 | e-ISSN: 2317-6385
How to cite this article:

Alves GC, Silva SD, Chequer FM, de Castro WV, Baldoni AO, Farkas A, et al. Software for dose adjustment of antimicrobials. Implications for plasma concentrations and pratical limitations [letter]. einstein (São Paulo). 2020;18:eCE5858. http://dx.doi.org/ 10.31744/einstein journal/2020CE5858

Received on:

May 15, 2020

Accepted on: July 10,2020

\section{Copyright 2020}

\section{(c) By}

This content is licensed

under a Creative Commons

Attribution 4.0 International License.
LETTER TO THE EDITOR

\section{Software for dose adjustment of} antimicrobials. Implications for plasma concentrations and pratical limitations

Software para ajuste de doses de antimicrobianos. Implicações nas concentrações plasmáticas e limitações práticas \author{
Jason Alexander Roberts ${ }^{4}$, Cristina Sanches ${ }^{1}$

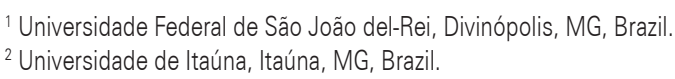

Geisa Cristina da Silva Alves ${ }^{1,2}$, Samuel Dutra da Silva ${ }^{1,2}$, Farah Maria Drumond Chequer ${ }^{1}$, Whocely Victor de Castro ${ }^{1}$, André Oliveira Baldoni', Andras Farkas ${ }^{3}$, Gergely Daróczi ${ }^{3}$,

DOI: 10.31744/einstein_journal/2020CE5858

Dear Editor,

This letter is designed to complement data published by Silva et al., ${ }^{(1)}$ presenting the results of plasma concentrations of patients who used piperacillin (PIP) in an empirical dose (ED) or dose adjusted (DA) by means of the software Optimum Dosing Strategies (ID-ODS). In addition, it describes some limiting aspects observed by the authors when using the software in the reality of a Brazilian hospital.

Currently, there are some types of software available worldwide for dose adjustment of antibiotics, which use specific data of the patient, together with pharmacokinetic population models..$^{(2,3)}$ Therefore, in case of no individual data on plasma concentrations available, the software can estimate individualized doses with high capacity and accuracy to achieve the target concentrations. ${ }^{(2,3)}$ Moreover, it can be easily integrated to the medical record to enable clinical management of the critical patient, at bedside. ${ }^{(2,4)}$ Hence, Silva et al., ${ }^{(1)}$ translated and performed the linguistic and cultural validation of a dose adjustment software, with further randomized clinical trial comparing the outcome between the Groups ED and DA for PIP. The software was configured for the pharmacokinetic/pharmacodynamic (PK/PD) target, with $50 \%$ of time when the free concentrations were above the minimum inhibitory concentration (50\%fT $>$ MIC) and a MIC of $8 \mathrm{mg} / \mathrm{L}$.

The authors did not observe differences in the clinical outcomes between the groups. During the study, three blood samples were collected at day 5 of PIP treatment, at the same dose intervals, and they were later processed and analyzed. To evaluate microbiological efficacy, \% $\mathrm{fT}>\mathrm{MIC}$ was calculated considering plasma protein binding of $30 \%$ and extrapolating the decay curve for plasma MIC up to $8 \mathrm{mg} / \mathrm{L}$, based on the formula $\mathrm{K}_{\mathrm{el}}=\left(\operatorname{lnC}_{1}-\operatorname{lnC}_{2}\right) /$ $\left(\mathrm{T}_{2}-\mathrm{T}_{1}\right)$, in which $\mathrm{Kel}$ is the elimination rate constant, and $\mathrm{C} 1$ and $\mathrm{C} 2$ are the plasma concentrations at times $\mathrm{T} 1$ and $\mathrm{T} 2$. The results obtained were minimum concentration $\left(\mathrm{C}_{\min }\right)$ for Group ED $(\mathrm{n}=12)$ median of $21.30 \mathrm{mg} / \mathrm{L}$ (1.7-271.97 for minimum and maximum values) and coefficient of variation 
$(\mathrm{CV})$ of $75 \%$, whereas for Group DA $(\mathrm{n}=9)$, the values were $12.83 \mathrm{mg} / \mathrm{L}(3.25-28.57)$ and $14.6 \%,(\mathrm{p}=0.650$, Mann-Whitney test), respectively.

Although there was no statistical difference between the groups, it is important to highlight the Group ED presented greater variability in both inefficacy and toxicity limits ${ }^{(5)}$ as compared to Group DA. Therefore, $42 \%(n=5)$ of patients from Group ED with $\mathrm{C}_{\min }$ over ten-fold the MIC of $8 \mathrm{mg} / \mathrm{L}$ versus $22.2 \% \quad(n=2)$ in Group DA. Furthermore, $\mathrm{C}_{\min }$ was greater than the toxic concentration of $150 \mathrm{mg} / \mathrm{L}$ in $33.3 \%(n=4)$ of patients in Group ED versus 0\% in Group DA. Simultaneously, in Group ED, $25 \%(\mathrm{n}=3)$ of patients were below $50 \% \mathrm{fT}>\mathrm{MIC}$, as compared to $11 \%(\mathrm{n}=1)$ in Group DA.

In addition, to use dose adjustment software in an efficient manner, some practical limitations observed when carrying out the study should be addressed and discussed, besides those previously presented by Silva et al.,(1) The limitations are difficulty in estimating weight and height in critical patients at intensive care units (ICU), and in these cases, formulas not validated for critical patients are used; lack of confidence to work with DA, for both nursing team, ${ }^{(1)}$ and prescribers' team, who routinely use standardized antimicrobial doses recommended by manufacturers; and increased direct costs of medications, due to no intravenous mixture unit available for aseptic dilution, considering the fractionated vials were discarded, which did not contribute to reducing costs in the unit.

It is worth mentioning that these limitations could be extrapolated to a wide variety of services available in the country, and it is crucial that structural adjustments and appropriate work processes be implemented to expand the use of such technologies. Finally, the use of the software in the studied population provided less variability in plasma concentrations and in PK/PD correlation, suggesting clinical safety in its employment. However, further studies are required, with larger samples and direct and indirect cost analyses of software implementation, taking into account the short-, medium- and long-term scenarios, and the availability of an intravenous mixture unit for aseptic dilution, to avoid unnecessary losses.

\section{ACKNOWLEDGMENTS}

To the Coordenação de Aperfeiçoamento de Pessoal de Nivel Superior (CAPES), Financing Code 001, and the Conselho Nacional de Desenvolvimento Científico e Tecnológico (CNPq) process 428671/2018-7; to the Universidade de Itaúna, for providing part of the supplies for pharmacokinetic analyses.

\section{AUTHORS' INFORMATION}

Alves GC: http://orcid.org/0000-0002-2023-8011

Silva SD: http://orcid.org/0000-0002-4287-3542

Chequer FM: http://orcid.org/0000-0003-3514-2132

de Castro WV: http://orcid.org/0000-0002-8354-1843

Baldoni AO: http://orcid.org/0000-0001-6379-0415

Farkas A: http://orcid.org/0000-0002-1335-4751

Daróczi G: http://orcid.org/0000-0003-3149-8537

Roberts JA: http://orcid.org/0000-0001-6218-435X

Sanches C: http://orcid.org/0000-0002-8562-1337

\section{REFERENCES}

1. Silva SD, Alves GC, Chequer FM, Farkas A, Daróczi G, Roberts JA, et al. Linguistic and cultural adaptation to the Portuguese language of antimicrobial dose adjustment software. einstein (São Paulo). 2020;18:eA05023. doi: 10.31744/einstein_journal/2020A05023.

2. Roberts JA, Abdul-Aziz MH, Lipman J, Mouton JW, Vinks AA, Felton TW, Hope WW, Farkas A, Neely MN, Schentag JJ, Drusano G, Frey OR, Theuretzbacher U, Kuti JL; International Society of Anti-Infective Pharmacology and the Pharmacokinetics and Pharmacodynamics Study Group of the European Society of Clinical Microbiology and Infectious Diseases. Individualised antibiotic dosing for patients who are critically ill: challenges and potential solutions. Lancet Infect Dis. 2014;14(6):498-509. Review.

3. Heil EL, Nicolau DP, Farkas A, Roberts JA, Thom KA. Pharmacodynamic target attainment for cefepime, meropenem, and piperacillin-tazobactam using a pharmacokinetic/pharmacodynamic-based dosing calculator in critically ill patients. Antimicrob Agents Chemother. 2018;62(9). pii: e01008-18.

4. Jelliffe R. Challenges in individualizing drug dosage for Intensive care unit patients: is augmented renal clearance what we really want to know? Some suggested management approaches and clinical software tools. Clin Pharmacokinet. 2016;55(8):897-905.

5. Beumier M, Casu GS, Hites M, Wolff F, Cotton F, Vincent JL, et al. Elevated $\beta$-lactam concentrations associated with neurological deterioration in ICL septic patients. Minerva Anestesiol. 2015;81 (5):497-506. 